\title{
Gene Cloning, Protein Expression and Functional Analysis of a type 3 Metallothionein with Bioaccumulation Potential from Sonneratia alba
}

\author{
Dewei Niu ${ }^{1,2}$, Shuaiguang $\mathrm{Li}^{1,2}$, Shanze $\mathrm{Yi}^{1,2}$, Lianghua Shen ${ }^{1,2}$, Meiyan Huang1,2, \\ Renchao Zhou ${ }^{3}$, Lee Charles Tan ${ }^{4}$, Mason Breitzig ${ }^{4}$, Feng Wang', 2* \\ ${ }^{1}$ Institute of Genomic Medicine, College of Pharmacy, Jinan University, Guangzhou 510632, China. \\ ${ }^{2}$ Guangdong Provincial Key Laboratory of Pharmacodynamic Constituents of TCM and New Drugs Research, \\ Jinan University, Guangzhou 510632, China \\ ${ }^{3}$ State Key Laboratory of Biocontrol and Guangdong Provincial Key Laboratory of Plant Resources, \\ School of Life Sciences, Sun Yat-Sen University, Guangzhou 510530, China \\ ${ }^{4}$ Department of Internal Medicine, Morsani College of Medicine, University of South Florida, \\ 12901 Bruce B. Downs Blvd, MDC 19, Tampa, FL 33612, USA.
}

Received: 4 April 2017

Accepted: 11 July 2017

\begin{abstract}
Sonneratia alba ( $S$. alba) is a mangrove species grown in brackish water of tropical and subtropical regions. Due to its unique environment, it has evolved various mechanisms for modulating salt and metal levels. In order to find the genes connected with bioaccumulation of metals, the root transcriptome annotation of Sonneratia alba was analyzed and a new metallothionein (MT) gene was cloned. Sequence analysis found that the new MT gene belongs to type 3 MT, which is mostly expressed in roots. A simple and efficient method was used to express the type 3 MT of $S$. alba (SaMT3) by transforming the recombinant expression vector pET15b-SaMT3 into Escherichia coli (E. coli) Rosetta-gami and induction with the optimal conditions of $500 \mu \mathrm{M}$ Isopropyl $\beta$-D-1-thiogalactopyranoside (IPTG) at $24^{\circ} \mathrm{C}$ for $12 \mathrm{~h} . \mathrm{OD}_{600}$ of $E$. coli cells expressing His fused SaMT3 protein after treated with $500 \mu \mathrm{M} \mathrm{Cu}^{2+}$ or $500 \mu \mathrm{M} \mathrm{Pb}^{2+}$ for $12 \mathrm{~h}$ can reach 1.01 or 0.98 , while $\mathrm{OD}_{600}$ of control cells expressing His-tag can reach only 0.81 or 0.75 . Both control cells and the cells expressing SaMT3 accumulated metals. Cells expressing SaMT3, however, accumulated more $\mathrm{Pb}^{2+}$ and $\mathrm{Cu}^{2+}$ (more than two times) than control cells. In vivo, real-time PCR showed that the SaMT3 transcript was induced significantly when stimulated with $250 \mu \mathrm{M}$, $500 \mu \mathrm{M}$, or $1,000 \mu \mathrm{M} \mathrm{Cu}^{2+}$ or $\mathrm{Pb}^{2+}$ for $24 \mathrm{~h}$ and $48 \mathrm{~h}$. Taken together, the expression of SaMT3 can increase $\mathrm{Cu}^{2+}$ and $\mathrm{Pb}^{2+}$ resistance and binding capacity of $E$. coli.
\end{abstract}

Keywords: bioaccumulation, $\mathrm{Cu}^{2+}$, metallothionein, metal tolerance, $\mathrm{Pb}^{2+}$, Sonneratia alba

*e-mail: jnubiopharm@126.com 


\section{Introduction}

Heavy metals are among the worst environmental pollutants in the world due to their highly toxic persistence, bioaccumulation, and high cost of governance [1]. Of all the metals, the 2 most prevalent pollutantsare $\mathrm{Cu}^{2+}$ and $\mathrm{Pb}^{2+}$ due to extensive use in industrial production [2]. $\mathrm{Pb}$ is a non-essential element and the content of $\mathrm{Pb}^{2+}$ in plants is used for assessing metal toxicity [3]. $\mathrm{Cu}$ is an essential trace element, but higher doses of it can cause metabolic disturbance and malformation. Currently, the greatest source of $\mathrm{Cu}^{2+}$ is industrial production [4-5].

The traditional method of removal of metals is by washing polluted water and soil with organic reagents [6]. However, using organic reagents has proven to be ineffective against $\mathrm{Cu}^{2+}$ and $\mathrm{Pb}^{2+}$. Furthermore, almost all of the washing reagents that successfully remove metals species from water and soil, also unfortunately disturb the balance of remaining metal ions [7]. Phytoremediation is defined as the use of plants to extract and sequester pollutants through physical, chemical, and biological processes and it has been reported to be cost-effective [8]. Plants able to tolerate and accumulate high concentrations of metals and with rapid growth rate and high biomass are considered to be ideal for phytoremediation [9]. Generally, plants protect themselves by expressing metal-chelating peptides under metal stress. MT was one of the most important metal-chelating peptides [4, 10]. According to Cys (C) residue arrangements, MTs were divided into four classes. Types 1-3 of MTs all contain 2 C-rich regions. Type 1 MTs have exclusive $\mathrm{C}-\mathrm{X}-\mathrm{C}$ clusters in their $\mathrm{N}$ - and $\mathrm{C}$-terminal regions while type 2 has a CC motif, 5 C-X-C motifs, and a C-X-X-C motif. A CC, a C-XX-C, and $2 \mathrm{C}-\mathrm{X}-\mathrm{C}$ motifs existed in N-terminal (CCXXXCXCXXXCXCXXXCXXC), and $3 \mathrm{C}$-X-C motifs are located in C-terminal (CXCXXXCXCXXCXCX).X stands for the amino acids except C. Type 3 MTs contain a conserved sequence in the N-terminal domain (CGNCDC) and $6 \mathrm{C}$ residues arranged in exclusive $\mathrm{C}-\mathrm{X}-\mathrm{C}$ clusters in the $\mathrm{C}$-terminal. Type 3 MTs are highly conserved in four types of MTs and are mostly expressed in roots, which was the main tissue for plants to touch metal ions in soil [11]. [12] reported that the $\mathrm{Cu}^{2+}$ and $\mathrm{Cd}^{2+}$ resistance of yeast expressing MT3 or MT2b1 of barley was higher than yeast expressing other MTs of barley. MT3 could have a physiological function as a $\mathrm{Zn}^{2+} / \mathrm{Cu}^{2+} / \mathrm{Cd}^{2+}$ homeostasis protein responding to cytosolic changes in metal concentrations [12]. Type 4 MTs are early cysteinelabelled protein (Ec-1), which contained 3 Cys-rich regions, separated in sequence by short linker. The smaller $\mathrm{N}$-terminal domain is formed by the $\mathrm{N}$-terminal Cys-rich region and hosts a Zn2Cys6 cluster [13].

Sonneratia alba (S. alba), a member of the mangrove family, is commonly grown in brackish water in tropical and subtropical regions. Among all mangrove plants, only $S$. alba can grow on the seaward side due to its high tolerance to salt stress [14]. Although $S$. alba plays a critical role in metal binding, few studies have focused on its associated genes. As a gene correlating with adjusting metal homeostasis, MTs from roots of $S$. alba are more likely to have potential for bioaccumulation.

In this study, an $M T$ gene from $S$. alba root was discovered and cloned through root transcriptome annotation. Sequence analysis showed that the new gene belonged to the type 3 MT family. Subsequently, the $\mathrm{Cu}^{2+}$ and $\mathrm{Pb}^{2+}$ bioaccumulation capacity and tolerance of $E$. coli expressing SaMT3 were investigated. In addition, real-time PCR was performed to analyze the variation of SaMT3 transcripts in leaf, stem, and root tissues after treatment with $\mathrm{Cu}^{2+}$ or $\mathrm{Pb}^{2+}$. This work contributes to a better understanding of plant MTs and it provides a foundation for further functional analysis of proteins with bioaccumulation potential on the environment.

\section{Experimental}

\section{RNA Isolation and cDNA Synthesis}

A traditional method was used to cultivate plant and extract total RNA [15]. cDNA synthesis was performed using a Prime Script II $1^{\text {st }}$ Strand cDNA Synthesis Kit (Takara, Japan).

\section{Analysis of Rare Codons and Encoded Amino Acid Sequences of SaMT3}

The homologs of SaMT3 from other species were searched by the BLASTP program (ncbi.nlm.nih. gov). The Clustal X program was used to compare MT sequences from $S$. alba and other species. Clustal X and the MEGA 5.05 program were used to construct a phylogenetic tree.

\section{Cloning the ORF of SaMT3 into Expression Vector}

The coding region of SaMT3 was amplified by PCR using the cDNA of $S$. alba as a template. The primers were designed based on the transcriptome annotation of $S$. alba. The sequences of the primers are as follows: forward primer (FP) 5'ATGTCGGACAAGTGCGGGAACTGC3' and reverse primer (RP) 5'TCAGTGGCCACAGGTGCAGGCTGT3'. The PCR products were ligated into the modified expression vector $p E T 15 b$ (Sma I) and then sequenced directly by the Invitrogen Company.

\section{Expression and Western Blot Analysis of SaMT3}

The pET15b-SaMT3 expression plasmid was transformed into E. coli Rosetta-g765 cells. The protein 
expression was then induced with the optimal conditions of $500 \mu \mathrm{M}$ IPTG at $24^{\circ} \mathrm{C}$ for $12 \mathrm{~h}$. Then mouse anti-His IgG antibody (Santa Cruz, USA) was used to analyze the expression of SaMT3.

\section{Tolerance of $E$. coli Expressing SaMT3 to $\mathrm{Cu}^{2+}$ and $\mathrm{Pb}^{2+}$}

A reported method was used to analyze the tolerance of E. coli expressing SaMT3 to $\mathrm{Cu}^{2+}$ and $\mathrm{Pb}^{2+}$ [5]. E. coli cells (harboring pET15b-SaMT3) were grown at $37^{\circ} \mathrm{C}$ until they were grown to mid-logarithmic phase $\left(\mathrm{OD}_{600}=0.6\right)$. Then IPTG was added at a final concentration of $500 \mu \mathrm{M}$. After $0.5 \mathrm{~h}, \mathrm{~Pb}^{2+}$ or $\mathrm{Cu}^{2+}$ were simultaneously added at a final concentration of $500 \mu \mathrm{M}$. E. coli cells (harboring pET15b) were treated identically as control. $\mathrm{OD}_{600}$ measurements were conducted to analyze the effects of $\mathrm{Cu}^{2+}$ and $\mathrm{Pb}^{2+}$ on bacterial growth at $1 \mathrm{~h}$ intervals for $12 \mathrm{~h}$.

\section{Bioaccumulation Capacity of E. coli Expressing SaMT3}

A reported method was used to analyze the bioaccumulation capacity of $E$. coli expressing SaMT3 [16]. After induction with $500 \mu \mathrm{M}$ IPTG for $12 \mathrm{~h}$, E. coli were centrifuged at $5,000 \mathrm{~g}$ for $10 \mathrm{~min}$. The supernatant was discarded. $0.1 \mathrm{~g}$ E. coli (wet weight) were suspended into $100 \mathrm{~mL}$ of $\mathrm{LB}$ medium with metal $\left(\mathrm{Cu}^{2+}\right.$ or $\left.\mathrm{Pb}^{2+}\right)$ at a final concentration of $250 \mu \mathrm{M}, 500 \mu \mathrm{M}$, or $1,000 \mu \mathrm{M}$. The bioaccumulation conditions $\left(25^{\circ} \mathrm{C}, \mathrm{pH} 5.0,75 \mathrm{rpm}\right)$ were identical with the reported method. After $24 \mathrm{~h}$, samples were taken from the solutions, and the metal concentration in the supernatants (Ce) was measured by inductively coupled plasma mass spectrometry (ICP-MS) (Elan DRC-e Perkin Elmer, USA). All experiments were repeated 3 times. The metal accumulation capacity ( $q, \mathrm{mg} / \mathrm{g}$ cell) was calculated according to $q=\left(C_{0}-C \mathrm{e}\right)$ / $X$, where $C_{0}$ denotes the initial metal concentration $(\mathrm{mg} / \mathrm{L})$ and $X$ denotes the initial $E$. coli cell concentration $(\mathrm{g} / \mathrm{L})$.

\section{Real-Time PCR}

Relative transcript levels of SaMT3 in various tissues (roots, stems, and leaves) after acute exposure to $\mathrm{Cu}^{2+}$ or $\mathrm{Pb}^{2+}$ were determined by real-time PCR. Specific primers for SaMT3 genes and the reference gene $G A P D H$ were designed based on the related sequence in transcriptome of $S$. alba. Real-time PCR was performed as previously described and the relative gene expression levels were calculated with the $2^{-\Delta \Delta \mathrm{Ct}}$ method using $G A P D H$ for normalization [17].

\section{$\mathrm{Cu}^{2+}$ and $\mathrm{Pb}^{2+}$ Bioaccumulation in S. alba}

For the experiment on metal treatment, one-monthold plants were transferred to Hoagland's nutrient solution and allowed to acclimatize. 6-week-old plants were submerged in aqueous solutions of $\mathrm{Cu}^{2+}$ and $\mathrm{Cd}^{2+}$ at different concentrations $(250,500,1,000 \mu \mathrm{M})$ for $48 \mathrm{~h}$. Control plants were submerged in Hoagland's nutrient without metal [4]. $\mathrm{Cu}^{2+}$ and $\mathrm{Pb}^{2+}$ contents were measured in roots, stems, and leaves of both control and metal-treated plants. Tissues of both control and $\mathrm{Cu}^{2+}$ and $\mathrm{Pb}^{2+}$-treated plants were dried at $80^{\circ} \mathrm{C}$ for 2 days, weighed, and placed in separate beakers. Samples were then mineralized in a microwave digestion instrument (Cen, USA), using specialized teflon vessels previously soaked in a solution of $\mathrm{H}_{2} \mathrm{O}$ and $\mathrm{HNO}_{3}$ (v:v). After mineralization, the digestion solution was adjusted to a final volume of $5 \mathrm{~mL} 65 \% \mathrm{HNO}_{3}$ and $1 \mathrm{~mL} 30 \% \mathrm{H}_{2} \mathrm{O}_{2}$. $\mathrm{Cu}^{2+}$ and $\mathrm{Pb}^{2+}$ content was determined by ICPMS after calibration for each metal using certified reference materials ICP-Multi Element Standard Solution XVI standard $\left(\mathrm{Cu}^{2+} 100 \pm 5 \mathrm{mg} / \mathrm{L} ; \mathrm{Pb}^{2+} 100 \pm 5 \mathrm{mg} / \mathrm{L}\right)$ and results reported as $\mathrm{mg} \mathrm{kg}^{-1}$ dry weight [18].

\section{Statistical Analysis}

Data were expressed as mean \pm standard deviation. The data were analyzed using Student's t-test, only if $p<0.05, p<0.01$, and $p<0.001$ were the differences considered to be statistically significant. SPSS for

Table 1. Bioaccumulation of $\mathrm{Cu}^{2+}$ and $\mathrm{Pb}^{2+}$ in root, stem, and leaf of S. alba.

\begin{tabular}{|c|c|c|c|c|c|c|}
\hline Sample & \multicolumn{3}{|c|}{ Weight of element (mg / kg dry weight) } & \multicolumn{3}{|c|}{ Level of significance } \\
\hline Metal stress & $0 \mu \mathrm{M}$ & $500 \mu \mathrm{M}$ & $1,000 \mu \mathrm{M}$ & $0 * 500$ & $0 * 1,000$ & $500 * 1,000$ \\
\hline $\mathrm{Cu}^{2+}$ root & $2.96 \pm 0.71$ & $14.51 \pm 1.3$ & $21.82 \pm 1.6$ & $* * *$ & $* * *$ & $* *$ \\
\hline $\mathrm{Cu}^{2+}$ stem & $1.91 \pm 0.13$ & $3.93 \pm 0.72$ & $4.25 \pm 0.40$ & $* * *$ & $* * *$ & ns \\
\hline $\mathrm{Cu}^{2+}$ leaf & $2.28 \pm 0.25$ & $4.07 \pm 0.15$ & $9.84 \pm 0.22$ & $* *$ & $* *$ & ns \\
\hline $\mathrm{Pb}^{2+}$ root & $1.64 \pm 0.52$ & $15.08 \pm 1.20$ & $30.03 \pm 1.01$ & $* * *$ & $* * *$ & $* * *$ \\
\hline $\mathrm{Pb}^{2+}$ stem & $1.83 \pm 0.15$ & $9.50 \pm 0.82$ & $16.03 \pm 0.99$ & $* * *$ & $* * *$ & $* *$ \\
\hline $\mathrm{Pb}^{2+}$ leaf & $2.62 \pm 0.16$ & $12.13 \pm 0.58$ & $24.03 \pm 1.28$ & $* * *$ & $* * *$ & $* * *$ \\
\hline
\end{tabular}

Data were expressed as mean \pm standard deviation; ns denotes no significant difference; $* * p<0.01 ; * * * p<0.001$ 


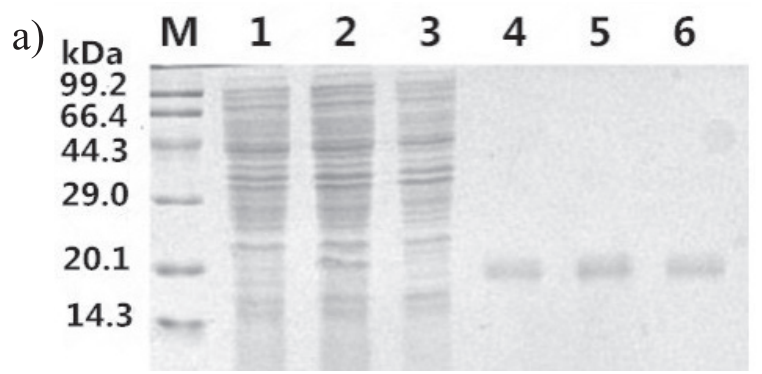

b)

1

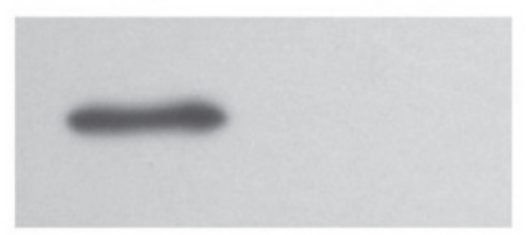

Fig. 1. a) SDS-PAGE analysis of expression of SaMT3 protein in E. coli Rosetta-gami. Lane M, protein marker; lane 1, the lysate of uninduced $E$. coli (harboring $p E T 15 b-S a M T 3$ ) grown at $37^{\circ} \mathrm{C}$ for $12 \mathrm{~h}$; lane 2, the lysate of E. coli (harboring $p E T 15 b-S a M T 3$ ) induced with IPTG at $24^{\circ} \mathrm{C}$ for $12 \mathrm{~h}$; lane 3, the lysate of uninduced E. coli (harboring $p E T 15 b-S a M T 3$ ) grown in the same condition as lane 2; lanes 4-6, the purified SaMT3 by Ni-NTA affinity chromatography purification. b) Western blot detection of fusion protein with anti-His mAb. Lane 1, purified SaMT3 by Ni-NTA affinity chromatography purification; lane 2, uninduced E. coli lysate.

Windows software (version 13.0; SPSS Inc, Chicago, IL, USA) was used to analysis the data.

\section{Results}

\section{Molecular Cloning and Sequence Analysis of SaMT3}

Through analysis of the root transcriptome annotation of $S$. alba, the only new $M T$ gene that belongs to the type 3 MT family was cloned in this study. The cDNA sequence of SaMT3 was submitted to GenBank (Accession No. KX453296). It contained a 201-bp open reading frame that encoded an $8.6 \mathrm{kDa}$ polypeptide of 66 amino acid residues with a predicted pI of 5.08 (Supplement Fig. 1a). The nucleotide sequence of SaMT3 showed a high sequence similarity with type 3 MT from other plants found in NCBI (National Center for Biotechnology Information). CPMT3 from Carica papaya was determined to have the highest sequence similarity (86\%) with SaMT3 (Supplement Table 1). Sequence analysis showed that all selected type 3 MTs contained a conserved sequence (Cys-Gly-Asn-CysAsp-Cys) in its N-terminal domain and 6 Cys residues arranged in exclusive $\mathrm{C}-\mathrm{X}-\mathrm{C}$ clusters in the $\mathrm{C}$-terminal (supplement Fig. 1b). We found that the topology was largely consistent with their subtype classification (Supplement Fig. 1c).

\section{Expression and Western Blot Analysis of SaMT3}

The conditions for expressing soluble form of SaMT3 were optimized and the best conditions were induction with $500 \mu \mathrm{M}$ IPTG at $24^{\circ} \mathrm{C}$ for $12 \mathrm{~h}$. The protein was almost in soluble form with a molecular weight of approximately $21 \mathrm{kDa}$. Western blotting indicated that the SaMT3 protein fused with His-tag showed a strong reaction against His-tag antibody, and the specific reaction bands were located at approximately $21 \mathrm{kDa}$ (Fig. 2b). This result provided further evidence that the recombinant SaMT3 protein was correctly fused to the His-tag of the vector $(p E T 15 b)$.

\section{Tolerance of $E$. coli Expressing SaMT3 to $\mathrm{Pb}^{2+}$ and $\mathrm{Cu}^{2+}$}

Dontrol E. coli (harboring pET15b) and E. coli (harboring $p E T 15 b$-SaMT3) were used to analyze their
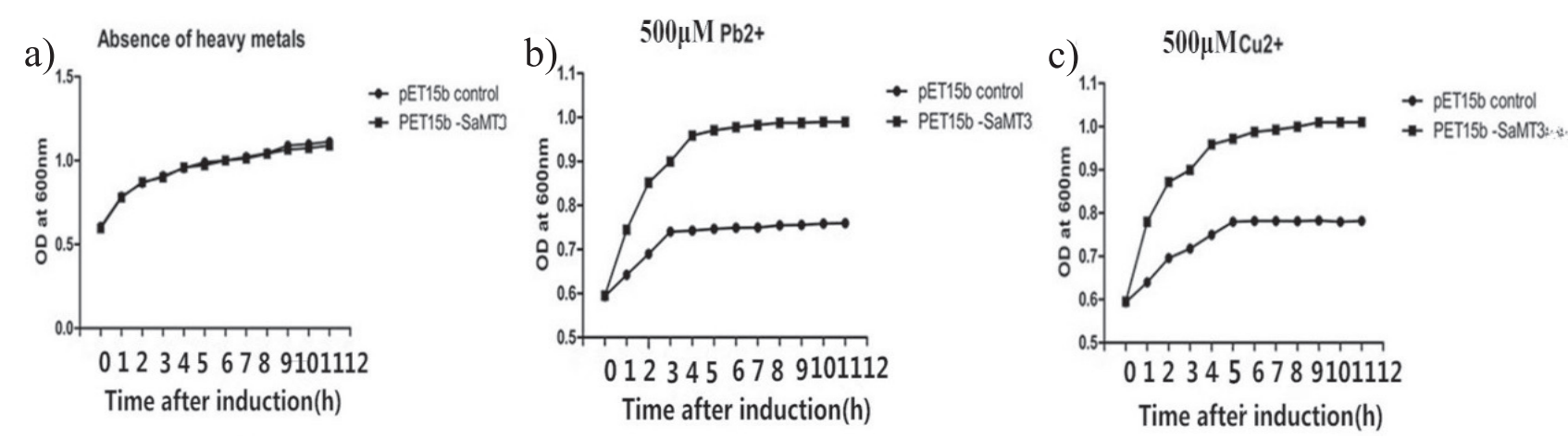

Fig. 2. Growth kinetics of $E$. coli cells harboring different plasmids in $\mathrm{LB}$ a) and LB containing $500 \mu \mathrm{M} \mathrm{Pb}^{2+}$ b) and $500 \mu \mathrm{M} \mathrm{Cu} u^{2+}$ ). IPTG was added at a final concentration of $500 \mu \mathrm{M}$ when $\mathrm{OD}_{600}$ reached 0.6 . After induction with IPTG for $0.5 \mathrm{~h}, \mathrm{~Pb}^{2+}$ or $\mathrm{Cu}^{2+}$ was added. The bacterial cells harboring $p E T 15 b$ and $p E T 15 b-S a M T 3$ were indicated as $p E T 15 b$ control and $p E T 15 b-S a M T 3$, respectively. 
tolerance to $\mathrm{Pb}^{2+}$ and $\mathrm{Cu}^{2+}$. With no metal ion addition, all cells grew well (Fig. 2a), which showed that the expression of SaMT3 had no effect on the growth of E. coli cells. The control cells almost stopped growth after treatment with $500 \mu \mathrm{M} \mathrm{Pb}^{2+}$ for $4 \mathrm{~h}$ when $\mathrm{OD}_{600}$ reached 0.74, whereas cells expressing SaMT3 stopped growth after treatment with $500 \mu \mathrm{M} \mathrm{Pb}^{2+}$ for $8 \mathrm{~h}$ when $\mathrm{OD}_{600}$ reached 0.98 (Fig. 2b). The control cells almost stopped growth after treatment with $500 \mu \mathrm{M} \mathrm{Cu}^{2+}$ for $6 \mathrm{~h}$ when $\mathrm{OD}_{600}$ reached 0.81 , whereas cells expressing SaMT3 stopped growth after treatment with $500 \mu \mathrm{M}$ $\mathrm{Cu}^{2+}$ for $8 \mathrm{~h}$ when $\mathrm{OD}_{600}$ reached 1.01 (Fig. 2c). The results are consistent with the research of $\mathrm{Li}$ et al. [19-20]. With no metal ions addition, all cells grew well, and the cells almost stopped growth for $6 \mathrm{~h}$ when $\mathrm{OD}_{600}$ reached 1.5, and the control cells almost stopped growth after treatment with $500 \mu \mathrm{M} \mathrm{Cu}^{2+}$ for $7 \mathrm{~h}$ when $\mathrm{OD}_{600}$ reached 1.1, whereas cells expressing JcMT2 stopped growth after treatment with $500 \mu \mathrm{M} \mathrm{Pb}^{2+}$ for $12 \mathrm{~h}$ when $\mathrm{OD}_{600}$ reached 1.5.

\section{Bioaccumulation Capacity of E. coli Expressing SaMT3}

To measure the bioaccumulation capacity of $E$. coli cells to $\mathrm{Pb}^{2+}$ and $\mathrm{Cu}^{2+}$, cells were grown for $24 \mathrm{~h}$ in the

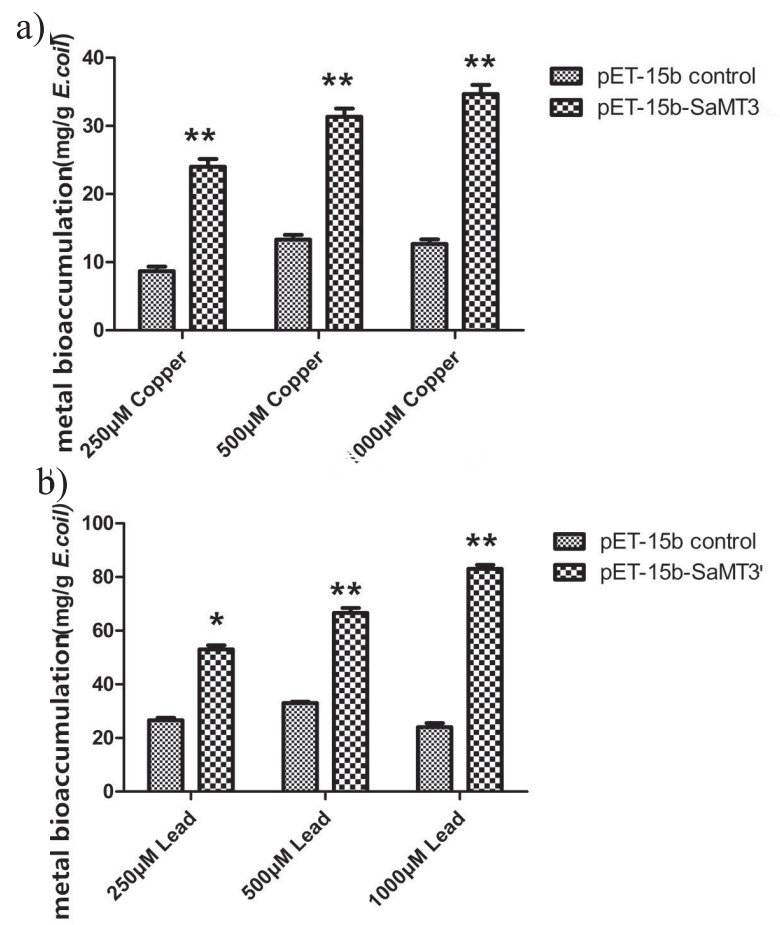

Fig. 3. Bioaccumulation capacity of E. coli cells harboring different plasmids: a) metal bioaccumulation of $E$. coli cells treated with $250 \mu \mathrm{M}, 500 \mu \mathrm{M}$, and $1,000 \mu \mathrm{M} \mathrm{Cu}{ }^{2+}$; and b) bioaccumulation of $E$. coli cells treated with $250 \mu \mathrm{M}, 500 \mu \mathrm{M}$, and $1,000 \mu \mathrm{M} \mathrm{Pb}^{2+}$; the bacterial cells harboring $p E T 15 b$ and $p E T 15 b-S a M T 3$ were indicated as $p E T 15 b$ control and $p E T 15 b-$ SaMT3, respectively

*significance of difference as $p<0.05$, **very significant differences $(p<0.01)$ compared with $p E T 15 b$ control group medium with $\mathrm{Pb}^{2+}$ or $\mathrm{Cu}^{2+}$ at different concentrations $(250,500,1,000 \mu \mathrm{M})$. The bioaccumulation capacity was shown in Fig. 3. All cells can accumulate $\mathrm{Pb}^{2+}$ or $\mathrm{Cu}^{2+}$. E. coli (harboring pET15b-SaMT3), however, accumulated markedly more $\mathrm{Pb}^{2+}$ and $\mathrm{Cu}^{2+}$ than that of the control cells. The metal accumulation capacity ( $q, \mathrm{mg} / \mathrm{g}$ cell) of induced E. coli (harboring pET15bSaMT3) is $83.2 \mathrm{mg} \mathrm{Pb}^{2+} / \mathrm{g}$ cell or $33.4 \mathrm{mg} \mathrm{Cu} \mathrm{Cu}^{2+} / \mathrm{g}$ cell in the medium with $1,000 \mu \mathrm{M} \mathrm{Pb}^{2+}$ or $\mathrm{Cu}^{2+}$, while the metal accumulation capacity $(q, \mathrm{mg} / \mathrm{g}$ cell) of induced $E$. coli (harboring $p E T 15$ ) showed $70.9 \%$ and $62.7 \%$ declines in accumulations of $\mathrm{Pb}^{2+}$ and $\mathrm{Cu}^{2+}$, respectively. The metal accumulation capacity $(q, \mathrm{mg} / \mathrm{g}$ cell) of induced $E$. coli

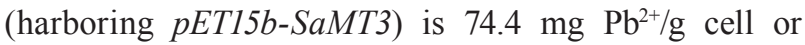
$31.1 \mathrm{mg} \mathrm{Cu}{ }^{2++} / \mathrm{g}$ cell in the medium, with $500 \mu \mathrm{M} \mathrm{Pb}^{2+}$ or $\mathrm{Cu}^{2+}$, while the metal accumulation capacity $(q$, $\mathrm{mg} / \mathrm{g}$ cell) of induced E. coli (harboring $p E T 15$ ) showed $67.2 \%$ and $56.3 \%$ declines in accumulation of $\mathrm{Pb}^{2+}$ and $\mathrm{Cu}^{2+}$, respectively. The metal accumulation capacity of $E$. coli expressing SaMT3 was gradually increased with the increasing of $\mathrm{Pb}^{2+}$ or $\mathrm{Cu}^{2+}$ concentration. The E. coli expressing SaMT3 can bind more $\mathrm{Pb}^{2+}$ than $\mathrm{Cu}^{2+}$. This result agreed with the metal-binding preference of MTs $\left(\mathrm{Cd}^{2+}>\mathrm{Pb}^{2+}>\mathrm{Cu}^{2+}>\mathrm{Zn}^{2+}\right)[21]$.

\section{Real-Time PCR}

The relative expression of SaMT3 in S. able was assessed by real-time PCR, normalized with GAPDH expression in leaf (Fig. 4c), stem (Fig. 4b), and root tissues (Fig. 4a). Real-time PCR standard curve of SaMT3 and GAPDH were used to show amplification efficiency. The amplification efficiencies of SaMT3 and $G A P D H$ were $96.4 \%$ and $95.9 \%$ (data not shown). SaMT3 was expressed in all tissues (leaf, root, and stem), but it was expressed the most abundantly in roots. When $S$. alba was treated with $500 \mu \mathrm{M} \mathrm{Pb}^{2+}$ for $24 \mathrm{~h}$ and $48 \mathrm{~h}$, the expression levels in roots were increased to nearly 25- and 17-fold, the expression levels in stems were increased to nearly 1.6 - and 1.4-fold, and the expression levels in leaves were increased to almost 19and 13-fold. When treated with $500 \mu \mathrm{M} \mathrm{Cu}^{2+}$ for $24 \mathrm{~h}$ and $48 \mathrm{~h}$, the expression levels in roots were increased to almost 12- and 6-fold, respectively, the expression levels in stems were increased to nearly 1.9- and 1.7-fold, and the expression levels in leaves were increased to nearly 9- and 7-fold, respectively. When $S$. alba was treated with $1,000 \mu \mathrm{M} \mathrm{Pb}^{2+}$ for $24 \mathrm{~h}$ and $48 \mathrm{~h}$, the expression levels in roots were increased by about 15- and 12-fold, the expression levels in stems were increased nearly 1.2and 1.5-fold, and the expression levels in leaves were increased by nearly 11- and 9-fold. When treated with $100 \mu \mathrm{M} \mathrm{Cu}^{2+}$ for $24 \mathrm{~h}$ and $48 \mathrm{~h}$, the expression levels in roots were increased to about 8- and 7-fold, respectively, the expression levels in stems were increased to nearly 1.9- and 1.4-fold, and the expression levels in leaves were increased to nearly 7 - and 6-fold, respectively. 


\section{$\mathrm{Cu}^{2+}$ and $\mathrm{Pb}^{2+}$ Bioaccumulation of $S$. alba}

The $\mathrm{Cu}^{2+}$ and $\mathrm{Pb}^{2+}$ contents in treated plants were directly proportional to $\mathrm{Cu}^{2+}$ and $\mathrm{Pb}^{2+}$ concentrations applied for each treatment. The binding ability of $S$. alba is $21.8 \mathrm{mg}, 4.3 \mathrm{mg}$, and $3.8 \mathrm{mg} \mathrm{Cu}^{2+}$ per $\mathrm{kg}$ of its roots, stems, and leaves when treated with $1,000 \mu \mathrm{M}$ of $\mathrm{Cu}^{2+}$ for $48 \mathrm{~h}$ (Table 1), compared with $30.0 \mathrm{mg}, 16.0 \mathrm{mg}$, and $24.0 \mathrm{mg} \mathrm{Pb}^{2+}$ per kilogram of its roots, stems, and leaves when treated with $1,000 \mu \mathrm{M}$ of $\mathrm{Pb}^{2+}$ for $24 \mathrm{~h}$ (Table 1). The bioaccumulation of $\mathrm{Cu}^{2+}$ is apparent in the root tissues while $\mathrm{Pb}^{2+}$ was detected in all three tissues (leaf, root, and stem).

a)
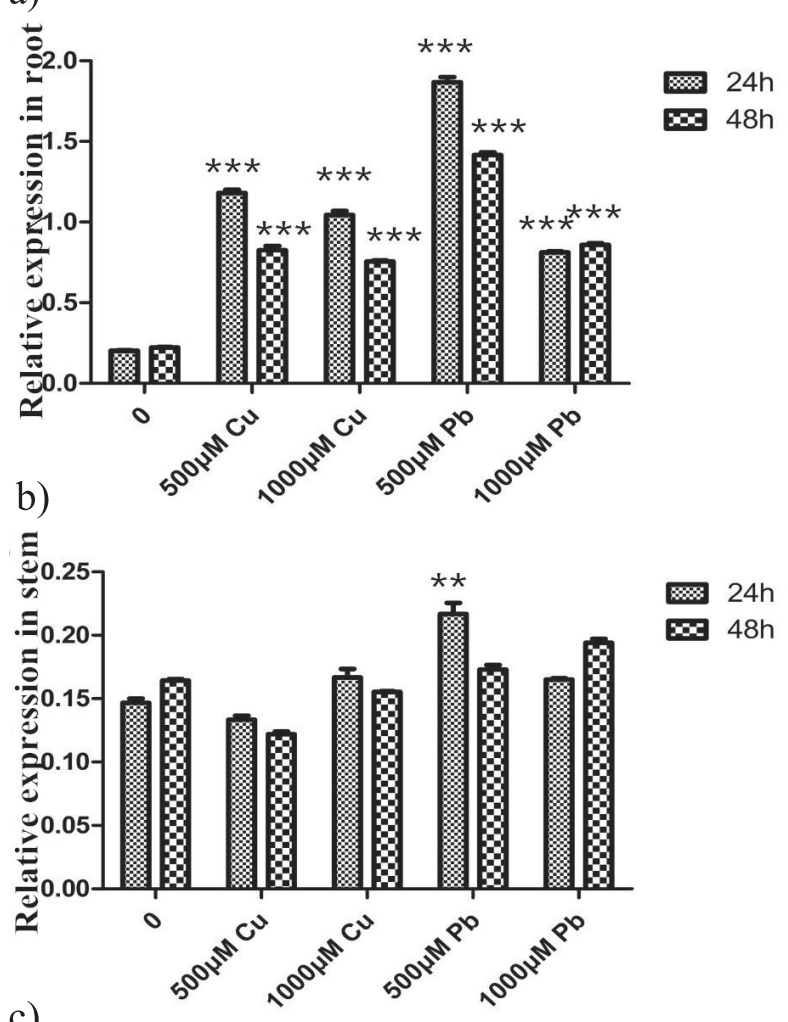

c)

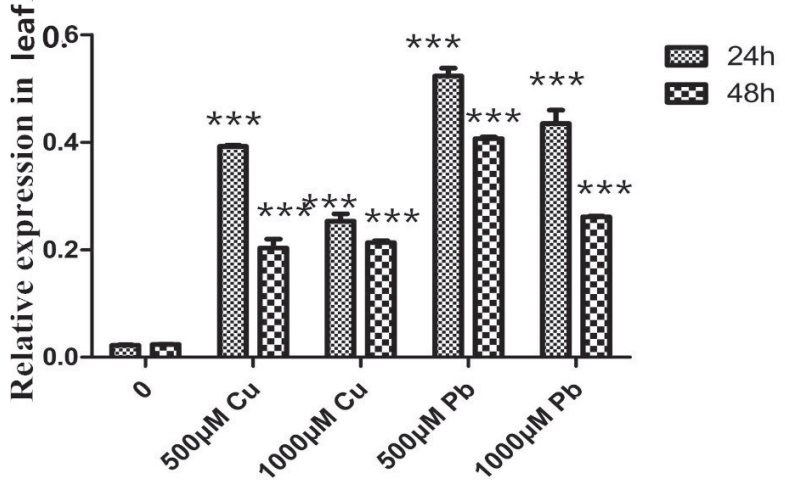

Fig. 4. Real-time PCR analysis of SaMT3 gene under $\mathrm{Cu}^{2+}$ and $\mathrm{Pb}^{2+}$ stress: a) root, b) stem, and c) leaf. Total RNA was isolated from control and treated plants and then converted to cDNA; after that, cDNA was subjected to real-time PCR

** $p<0.01$ and *** $p<0.001$ mean significant differences; vertical bars represent the mean $\pm \mathrm{SD}$.

\section{Discussion}

Phytoremediation is considered to be a promising biological technology for management and possibly even reversal of some metal pollutants. Malik is the first researcher to use $S$. alba for bioaccumulation and predict its function of chelation of metal ions in soil and wastewater [22-23]. Annie et al. studied the Pbaccumulating capacity of three common mangrove plants and found that the $\mathrm{Pb}^{2+}$-accumulating ability of $S$. alba was the strongest $\left(98.5 \mathrm{mg} \mathrm{kg}^{-1}\right)$ in root, followed by Avicennia marina $\left(63.0 \mathrm{mg} \mathrm{kg}^{-1}\right)$ in leaf and Rhizophora stylosa $\left(20.5 \mathrm{mg} \mathrm{kg}^{-1}\right)$ in leaf [24].

Plants have developed a mechanism to protect them from metal toxicity. The mechanism mainly consists of chelating polypeptides that immobilize metal ions inside the cell. Two kinds of plant metal-chelating peptides have been reported: enzymatically synthesized phytochelatins (PCs), and gene-encoded MTs [25-26]. PCs are a kind of molecule with multiple repetitions of the Glu-Cys dipeptide units followed by a terminal Gly. However, PCs can only improve plant tolerance to $\mathrm{Cd}^{2+}, \mathrm{Cu}^{2+}$, and $\mathrm{Zn}^{2+}$ [27], and the best inducer of PCs is cadmium [28]. It was reported that arabidopsis mutants lacking PC synthase had a definite cadmium-sensitive phenotype, but copper tolerance was not affected [29]. In this study, a novel MT3 gene was first cloned and analyzed, and sequence alignment showed that SaMT3 contained sequence signature of type 3 MT gene. Subsequently, the function of the novel MT3 gene on metal tolerance and accumulation was investigated.

Because MT protein is easy to digest and its molecular weight is low, it's still difficult to separate native MT from the organism directly [29]. Owing to its complexity in obtaining MT protein, a His-fused MT protein was developed in this study by cloning SaMT3 gene into heterologous expression vector $p E T 15 b$, and the recombinant protein was expressed in E. coli. The molecular weight of the His-fused SaMT3 expressed by $E$. coli is about $21 \mathrm{kDa}$ (Fig. 1a), despite the calculated mass of $9.65 \mathrm{kDa}$ (the molecular weight of SaMT3 protein is $7.05 \mathrm{kDa}$, and the molecular weight of His-tag is $2.60 \mathrm{kDa}$ ). The first reason for molecular weight deviation is that the compact structure of the protein containing multiple disulfide bridges (which precluded sufficient binding of SDS) leads to a lower negative charge and consequently to a higher apparent molecular mass in the gel. Although mercaptoethanol was added as a reducing agent to break the disulfide bridges, it is hard to ensure that all the disulfide bridges in SaMT3 were broken. The second reason for molecular weight deviation is that the metal thiolate clusters preserve the compact structure of the protein and restrict SDS loading to the surface of the protein [30-31]. Although the induced E. coli samples were not treated with the metals, the metals might come from the LB medium and other solution used in the process of ultrasonic decomposition and purification. The phenomenon of molecular weight deviation frequently 
appears in SDS-PAGE analysis of MTs [20, 32]. For example, SDS-PAGE results showed that the expression of OeMT2 in E. coli resulted in a $22 \mathrm{kDa}$ fusion protein (with His-Tag) despite the expected (calculated) mass of $8.4 \mathrm{kDa}[20]$.

To assess the tolerance of the E. coli cell expressing His or His-fused SaMT3 protein under metal ions stress, we called upon a frequently used method [33]. The $E$. coli cells were grown in the presence of $\mathrm{Cu}^{2+}$ and $\mathrm{Pb}^{2+}$ at a concentration of $500 \mu \mathrm{M}$. The results indicated an increase in tolerance and metal resistance of the Hisfused SaMT3 compared to that of His alone (Fig. 2). The data showed that SaMT3 performed a significant function in maintaining the metal balance and cell viability of the expression host E. coli. This could probably be due to the fact that SaMT3 expressed by E. coli could chelate metals. Similarly, exogenous expression KcMT2a from Kandelia candel also improved the metal tolerance ability of $E$. coli cells and metal-binding activities [33]. In order to better compare the bioaccumulation capacity of $\mathrm{His}$ and His fused SaMT3 protein, reported concentrations $(250 \mu \mathrm{M}, 500$ $\mu \mathrm{M}$, and $1,000 \mu \mathrm{M})$ and different time points were used (24 h, 48 h) [16]. These concentrations were frequently used in analyzing the metal-binding capacities of MTs [20]. The control E. coli (without expressing SaMT3) can also bind metal. This is likely due to the E. coli cell wall possessing a wide array of metal-binding peptides, like the newfound metal-efflux accessory protein RenB [34-36]. In addition, the expressed His tag by control group of $E$. coli cells can also bind metals. However, E. coli cells expressing His-fused SaMT3 protein can bind twice as much $\mathrm{Cu}^{2+}$ or $\mathrm{Pb}^{2+}$ than cells only expressing $\mathrm{His}$ in the medium with $1,000 \mu \mathrm{M} \mathrm{Cu}^{2+}$ or $1,000 \mu \mathrm{M} \mathrm{Pb}^{2+}$, which indicated that SaMT3 performed a function in binding $\mathrm{Cu}^{2+}$ and $\mathrm{Pb}^{2+}$ (Fig. 3). Ekrem Dundar studied the metal-binding ability of His-tag fused OeMT2, and they found that both control cells and the OeMT2 expressing cells accumulated metals. OeMT2 expressing cells, however, accumulated more $\mathrm{Cd}^{2+}$ and $\mathrm{Cu}^{2+}$ (more than two times) than control cells in the presence of $1,000 \mu \mathrm{M}$ metals after $24 \mathrm{~h}$ [34-35]. The expression level of SaMT3 was higher when $S$. alba was treated with $\mathrm{Cu}^{2+}$ and $\mathrm{Pb}^{2+}$ for $24 \mathrm{~h}$ than $48 \mathrm{~h}$. The results are consistent with those previously reported regarding the expression level of JcMT2 when treated with 500 or $1,000 \mu \mathrm{M} \mathrm{Cu}^{2+}$, which showed that the expression levels were increased nearly 20 -fold and 18 -fold when Jatropha curcas were treated with $500 \mu \mathrm{M} \mathrm{Cu}^{2+}$ for $24 \mathrm{~h}$ and $48 \mathrm{~h}$ [4].

To study the uptake and distribution of metals in the plants of metal-treated $S$. alba, ICPMS were performed. $\mathrm{Cu}^{2+}$ mainly accumulated in roots, but there were no significant changes of its accumulation in the stem and leaf tissues in metal-treated S. alba. $\mathrm{Pb}^{2+}$ bioaccumulation was increased in all 3 tissues of metal-treated $S$. alba compared to control plant tissue (Table 1). Similar phenomena on binding $\mathrm{Cu}^{2+}$ mostly in root also appeared in Jatropha curcas [4]. The $\mathrm{Pb}^{2+}$ binding capacity of $\mathrm{S}$. alba is stronger than $\mathrm{Cu} 2+$ binding capacity. These results fit the reports on distribution of $\mathrm{Pb}^{2+}$ in plant tissues (root, stem, and leaf) after treatment with metals [22]. The first reason for the different bioaccumulation between $\mathrm{Cu}^{2+}$ and $\mathrm{Pb}^{2+}$ in root, stem, and leaf tissues is that the transportation speed and transportation capability of these two metal ions is different [37]. The second reason for this difference is that metals used to treat $S$. alba may be caused by the different expression levels of proteins such as SaMT3, other MTs, and PCs [4].

\section{Acknowledgements}

This work was supported by the Traditional Chinese Medicine Bureau of Guangdong Province (NO. 20141065), Science and Technology Innovation Project from Department of Education of Guangdong Province (NO. 2012KJCX0017) and the Natural Science Foundation of Guangdong Province (NO. 2017A030313561). 


\section{Supporting Information}

Table 1. nucleotide sequence similarity of (MTs) between SaMT3a and other plants.

\begin{tabular}{|c|c|c|}
\hline Plants & GenBank Accession Number & Identity \\
\hline Carica papaya & Q96386.1 & $76 \%$ \\
\hline Salvia miltiorrhiza & AEQ54919.1 & $77 \%$ \\
\hline Hevea brasiliensis & ADR30789.1 & $74 \%$ \\
\hline Theobroma cacao & XP_007021480.1 & $70 \%$ \\
\hline Prosopis juliflora & ACC77568.1 \\
\hline
\end{tabular}

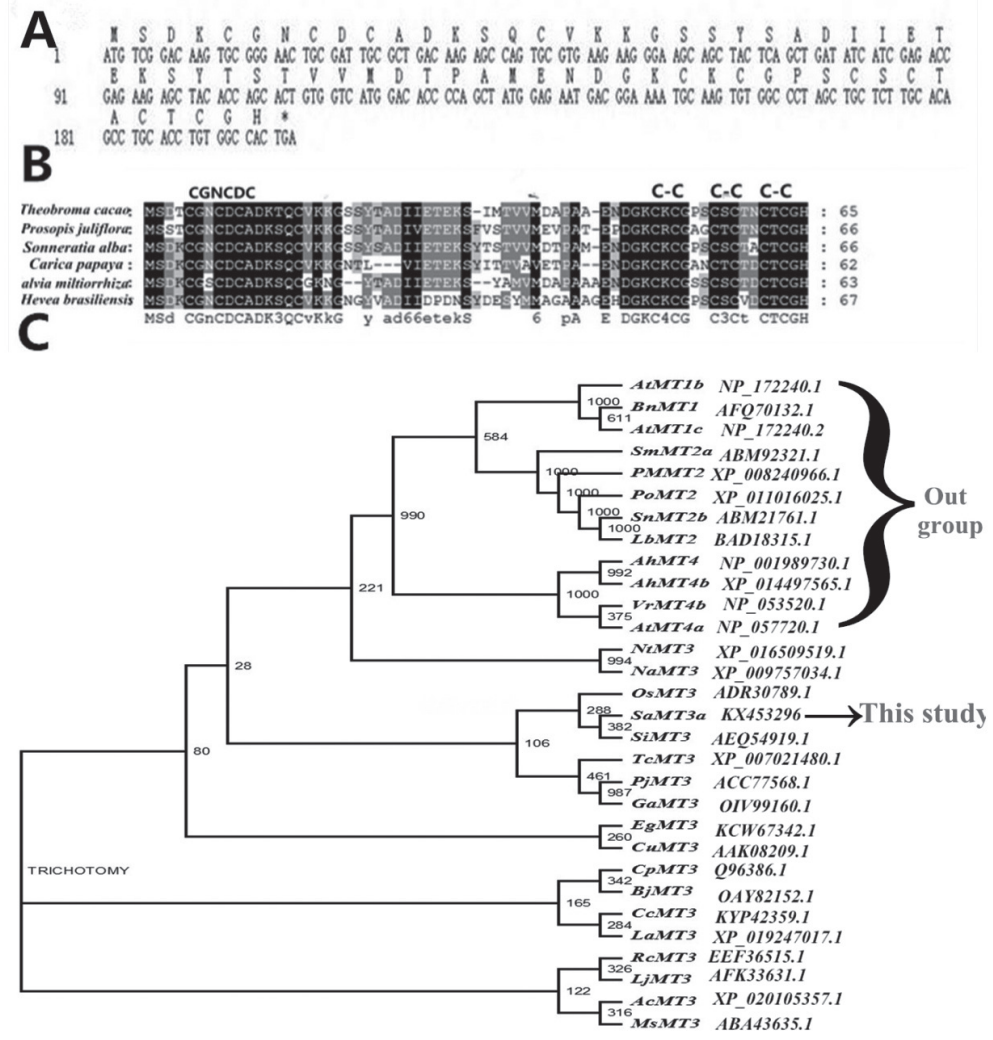

Supplementary Fig. 1. Sequence and phylogenetic tree analysis of SaMT3.

\section{References}

1. KAPOOR V., LI X., ELK M., CHANDRAN K., IMPELLITTERI C.A., DOMINGO J.W.S. Impact of Heavy Metals on Transcriptional and Physiological Activity of Nitrifying Bacteria. Environmental Science \& Technology, 49 (22), 13454, 2015.

2. TAN M.X., SUM Y.N., YING J.Y., ZHANG Y.G. A mesoporous poly-melamine-formaldehyde polymer as a solid sorbent for toxic metal removal.Energy \& Environmental Science, 6, 3254, 2013.

3. JOVIC M., STANKOVIC S. Human exposure to trace metals and possible public health risks via consumption of mussels Mytilus galloprovincialis from the Adriatic coastal area. Food and Chemical Toxicology, 70, 241, 2014.
4. MUDALKAR S., GOLLA R., SENGUPTA D., GHATTY S., REDDY A.R. Molecular cloning and characterisation of metallothionein type 2a gene from Jatropha curcas L., a promising biofuel plant. Molecular Biology Reports, 41 (1), 113, 2014.

5. HOUGH R.L., BREWARD N., YOUNG S.D., CROUT N.M.J., TYE A.M., MOIR A.M., THORNTON I. Assessing potential risk of heavy metal exposure from consumption of home-produced vegetables by urban populations. Environmental Health Perspectives, 112 (2), 215, 2004.

6. CHEN C.L., CHEN Y.H., XIE T.H., WANG M.K., WANG, G. Removal, redistribution, and potential risks of soil $\mathrm{Cd}, \mathrm{Pb}$, and $\mathrm{Zn}$ after washing with various extractants. Environmental Science and Pollution Research, 22 (21), 16881, 2015. 
7. UDOVIC M., LESTAN D. $\mathrm{Pb}, \mathrm{Zn}$ and $\mathrm{Cd}$ mobility, availability and fractionation in aged soil remediated by EDTA leaching.Chemosphere, 74 (10), 1367, 2009.

8. ULLAH A. Phytoremediation of heavy metals assisted by plant growth promoting (PGP) bacteria: A review. Environmental and Experimental Botany, 117, 28, 2015.

9. GARBISU C., ALKORTA I. Phytoextraction: a costeffective plant-based technology for the removal of metals from the environment. Bioresource Technology 77 (3), 229, 2001.

10. GUO W.J., BUNDITHYA W., GOLDSBROUGH P.B. Characterization of the Arabidopsis metallothionein gene family: tissue-specific expression and induction during senescence and in response to copper. New Phytologist, 159 (2), 369, 2003.

11. SHAHPIRI A., SOLEIMANIFARD I., ASADOLLAHI M.A. Functional characterization of a type 3 metallolthionein isoform (OsMTI-3a) from rice. International Journal of Biological Macromolecules, 73, 154, 2015.

12. HEGELUND J.N., SCHILLER M., KICHEY T., HANSEN T.H., PEDAS P., HUSTED S., SCHJOERRING J.K. Barley Metallothioneins: MT3 and MT4 Are Localized in the Grain Aleurone Layer and Show Differential Zinc Binding. Plant Physiology, 159 (3), 1125, 2012.

13. FREISINGER E. Structural features specific to plant metallothioneins. Journal of Biological Inorganic Chemistry, 16 (7), 1035, 2011.

14. HASEGAWA A., OYANAGI T., MINAGAWA R., FUJII Y., SASAMOTO H. An inverse relationship between allelopathic activity and salt tolerance in suspension cultures of three mangrove species, Sonneratia alba, S. caseolaris and S. ovata: development of a bioassay method for allelopathy, the protoplast co-culture method.Journal of Plant Research, 127 (6), 755, 2014.

15. TACCHI L., LARRAGOITE E.T., MUNOZ P., AMEMIYA C.T., SALINAS I. African Lungfish Reveal the Evolutionary Origins of Organized Mucosal Lymphoid Tissue in Vertebrates. Current Biology, 25 (18), 2417, 2015.

16. KAO W.C., CHIU Y.P., CHANG C.C., CHANG J.S. Localization effect on the metal biosorption capability of recombinant mammalian and fish metallothioneins in Escherichia coli. Biotechnology Progress, 22 (5), 1256, 2006.

17. LI X.Y., CHENG J.Y., ZHANG J., SILVA J.A.T., WANG C.X., SUN H.M. Validation of Reference Genes for Accurate Normalization of Gene Expression in Lilium davidii var. unicolor for Real Time Quantitative PCR. Plos One, 10 (10), 100, 2015.

18. MAZZEI V., GIANNETTO A., BRUNDO M.V., MAISANO M., FERRANTE M., COPAT C., MAUCERI A., LONGO G. Metallothioneins and heat shock proteins 70 in Armadillidium vulgare (Isopoda, Oniscidea) exposed to cadmium and lead. Ecotoxicology and Environmental Safety, 116, 99, 2015.

19. LI Y., CHEN Y.Y., YANG S.G. TIAN W.M. Cloning and characterization of HbMT2a, a metallothionein gene from Hevea brasiliensis Muell. Arg differently responds to abiotic stress and heavy metals. Biochemical and Biophysical Research Communications, 461 (1), 95, 2015.

20. DUNDAR E., SONMEZ G.D., UNVER T. Isolation, molecular characterization and functional analysis of OeMT2, an olive metallothionein with a bioremediation potential. Molecular Genetics and Genomics, 290 (1), 187, 2015.
21. LI M., ZHANG Z.B., SHANG J., LIANG B., YU L.L. Enhanced $\mathrm{Pb} 2+$ biosorption by recombinant Saccharomyces cerevisiae expressing human metallothionein. Monatshefte Fur Chemie, 145 (1), 235, 2014.

22. MALIK A., FENSHOLT R., MERTZ O. Mangrove exploitation effects on biodiversity and ecosystem services. Biodiversity and Conservation, 24 (14), 3543, 2015.

23. NORONHA-D'MELLO C.A., NAYAK G.N. Assessment of metal enrichment and their bioavailability in sediment and bioaccumulation by mangrove plant pneumatophores in a tropical (Zuari) estuary, west coast of India. Marine Pollution Bulletin, 110 (1), 221, 2016.

24. PAZ-ALBERTO A.M., CELESTINO A.B., SIGUA G.C. Phytoremediation of $\mathrm{Pb}$ in the sediment of a mangrove ecosystem. Journal of Soils and Sediments, 14 (1), 251, 2014.

25. DOMENECH J., ORIHUELA R., MIR G., MOLINAS M., ATRIAN S., CAPDEVILA M. The Cd-II-binding abilities of recombinant Quercus suber metallothionein: bridging the gap between phytochelatins and metallothioneins. Journal of Biological Inorganic Chemistry, 12 (6), 867, 2007.

26. FRANCHI N., PICCINNI E., FERRO D., BASSO G., SPOLAORE B., SANTOVITO G. BALLARIN L. Characterization and transcription studies of a phytochelatin synthase gene from the solitary tunicate Ciona intestinalis exposed to cadmium. Aquatic Toxicology, 152, 47, 2014.

27. LUO Z.B., WU C.H., ZHANG C., LI H., LIPKA U., POLLE A. The role of ectomycorrhizas in heavy metal stress tolerance of host plants. Environmental and Experimental Botany, 108, 47, 2014.

28. DAGO A., GONZALEZ I., ARINO C., DIAZ-CRUZ J.M., ESTEBAN M. Chemometrics applied to the analysis of induced phytochelatins in Hordeum vulgare plants stressed with various toxic non-essential metals and metalloids. Talanta, 118, 201, 2014.

29. GONG J.M., LEE D.A., SCHROEDER J.I. Long-distance root-to-shoot transport of phytochelatins and cadmium in Arabidopsis. Proceedings of the National Academy of Sciences of the United States of America, 100 (17), 10118, 2003.

30. PEROZA E.A., FREISINGER, E. Metal ion binding properties of Tricium aestivum E-c-1 metallothionein: evidence supporting two separate metal thiolate clusters. Journal of Biological Inorganic Chemistry, 12 (3), 377, 2007.

31. LOEBUS J., JOHANSSEN S., FREISINGER E. Identification of a binding site preference during Cadmium poisoning: probing the metallothionein domain y-Ec-1 embedded Zn2Cys6 zinc finger motive. Journal of Biological Inorganic Chemistry, 19, S215, 2014.

32. NAIK M.M., PANDEY A., DUBEY S.K. Pseudomonas aeruginosa strain WI-1 from Mandovi estuary possesses metallothionein to alleviate lead toxicity and promotes plant growth. Ecotoxicology and Environmental Safety, 79, 129, 2012.

33. ZHANG F.Q., WANG Y.S., SUN C.C., LOU Z.P., DONG J.D. A novel metallothionein gene from a mangrove plant Kandelia candel. Ecotoxicology, 21 (6), 1633, 2012.

34. BLERIOT C., GAULT M., GUEGUEN E., ARNOUX P., PIGNOL D., MANDRAND-BERTHELOT M.A., RODRIGUE A. Cu binding by the Escherichia coli metalefflux accessory protein RenB. Metallomics, 6 (8), 1400, 2014. 
35. WU Y., GUO Z.Q., ZHANG W., TAN Q.G., ZHANG L., GE X.L., CHEN M.D. Quantitative Relationship between Cadmium Uptake and the Kinetics of Phytochelatin Induction by Cadmium in a Marine Diatom.Scientific Reports, 6, 2016.

36. GONCALVES S.F. Sub-lethal cadmium exposure increases phytochelatin concentrations in the aquatic snail Lymnaea stagnalis. Science of the Total Environment, 568, 1054, 2016.
37. CHEN J.F., YUAN J.G., WU S.S., LIN B.Y., YANG Z.Y. Distribution of trace element contamination in sediments and riverine agricultural soils of the Zhongxin River, South China, and evaluation of local plants for biomonitoring. Journal of Environmental Monitoring, 14 (10), 2663, 2012. 